\title{
Distance Teaching of French Language for Special Purpose in an Islamic High School
}

\author{
Myrna Laksman-Huntley ${ }^{1}$, Ismirani Mardalena ${ }^{2}$, Ria Rizkya ${ }^{3}$ \\ \{laksman@ui.ac.id ${ }^{1}$, ismirani@ui.ac.id ${ }^{2}$, riarrizkya@gmail.com ${ }^{3}$ \}
}

French Department, Faculty of Humanities, Universitas Indonesia Depok, West Java, Indonesia ${ }^{1}$

\begin{abstract}
Errors in various communication aspects can arise in learning foreign languages due to the difference in language systems. Additionally, the way and time devoted to learning can affect the results. The educational basic standards and competencies of A1 French in MAN2 Kota Bogor, a madrasa, were difficult to achieve with only 45 minutes of lessons/week when added to their 2 x 45 minutes/week of Arabic, English, Indonesian and Sundanese lessons. Furthermore, Social Restrictions due to COVID-19 made the task even more challenging. Hasanah \& Saefullah in the same environment but with $2 \times 45$ minutes of study time also found that it was difficult to achieve the targets only with time extension (2017). Based on other research studying foreign language learning for specific purposes, foreign language distance-learning and motivation of foreign language learners through technology use, we applied teaching French for specific purposes with distance learning using several technologies. This article presents a distance-teaching of French for the specific purpose of tour guiding to achieve A1. This qualitative study was conducted with 15 year-XI students during school holidays using Powerpoint, WAG, and Google Meet for 12 days @ 2 hours/day. The results show that technology use with clear learning objectives motivate learners to reach their teaching targets.
\end{abstract}

Keywords: Teaching French as foreign language (FOS), Madrasah Aliyah (Islamic High School), learning French through FOS, language distance teaching technology.

\section{Introduction}

The COVID-19 pandemic has given severe sectoral impacts globally, including the education sector. Since mid-March 2020, the Government of Indonesia has issued a decree, namely the Circular Letter Number 4 of 2020 by the Ministry of Education and Culture (MoEC), on the application of distance teaching (Pembelajaran Jarak Jauh or PJJ) in Indonesia's educational system. Distance teaching has been implemented at all educational levels, from early childhood education, kindergarten or preschool education, elementary school, middle school, academic, vocational, and Islamic high schools, to higher education. Implementing distance teaching is a challenge in itself for both teachers and students because this method requires them to be proficient in technology. It is undeniable that in practice, as presented by Digtyar et al. [1], distance teaching for foreign language faces various problems, such as technology-related problems with the gadgets used which can affect the ability of teachers to deliver the teaching content effectively, especially to a non-foreign language specialized school like MAN 2 Kota Bogor.

Madrasah Aliyah Negeri (MAN) 2 Kota Bogor is an Islamic high school or Madrasa, located in the district of Bogor Timur, Kota Bogor [2]. Established in 1950, MAN 2 Kota Bogor is one of the three schools in Bogor that teaches French as one of the local content subjects 
(muatan lokal or mulok) which is compulsory for all students from freshman to senior year. This school has been aiming to arrange the French language teaching curriculum in accordance with the CECRL or Cadre Européen Commun de Référence pour les Langues 1 with the target of A1 proficiency. However, based upon the information given by the French teacher in MAN 2 Kota Bogor, the school is facing an obstacle in French teaching because of insufficient study time. French classes are only conducted once a week, @45minutes each session. Meanwhile, to achieve the target of A1 proficiency by the CECRL curriculum, learners must conduct 120 hours in French learning [3]. A1 is the beginner for language proficiency. According to the CECRL and CIEP Delf Dalf book [4], at this level, the linguistic performance in language production for both oral (Production Orale) and written (Production Écrite), learners are expected to be able to comprehend and utilize common everyday expressions and basic phrases aimed at the satisfaction of needs of a concrete type and also able to describe a person or an object with a simple phrase. In further detail, learners are expected to possess the ability to introduce themselves and others, as well as asking and answering questions related to their personal details such as their domicile, affiliation, and possessions. Hence, learners should be able to communicate easily with the interlocutor that speaks slowly, clearly, and cooperatively [3]. However, the limited study time in MAN 2 Kota Bogor along with the unexpected implementation of the distance teaching system has an increasing impact on the competence of French learning students because the teaching content is not delivered optimally. Hasanah and Saefullah [5] found that even extending to $2 \times 45$ minutes of study time a week at MAN in Cirebon cannot achieve early-level French learning targets.

Prior studies on foreign language teaching were found: in teaching English for specific purposes (ESP); for example, Pisarenko and Bondarev [6] found that visualizationbased technologies are effective in developing student's foreign language communicative competence and their imagination, memory, mental abilities and critical competence; while García-Sánchez [7] suggested an ubiquitous approach that motivated learners to be innovative and successful by combining individual and group work inside and outside classroom hours. Others studied the best way to organize and satisfy distance-teaching objectives of English as a foreign language: Didmanidze and Bagrationi [8] recommended use of email and computermediated communication and the Internet for communication and for collaborative projects with students across classes in different parts of the world. Digtyar et al. [1] found that distance teaching can be made competitive by using modern technologies such as electronic teaching manuals, platforms and case technologies, and Niyibizi et al. [9] offered reconceptualization of distance language teaching. Studies that address technology and foreign language teaching have also been conducted by Demouy et al. [10] who stated that knowledge of self-directed learners' practices, in this case by using mobile devices in contributing; while Bilyalova [11] added that Information and Communications Technology (ICT) in teaching a foreign language in high school could promote positive learning motivation.

Based on the described situation above, it can be said that the problem of French language teaching faced by MAN 2 Kota Bogor is how to make it efficient and adaptable to the study time given in the school curriculum, but to still achieve the target of improving the competence in French learning students through distance teaching. Referring to most previous works studying distance teaching, English as foreign language and English for specific purposes, this article presents an experiment of distance teaching French as a foreign language for specific purposes (FOS) out of the context, which is the school. This complimentary activity is given intensively during the school holiday (a total of 24 hours in one month) to students of MAN 2 
Kota Bogor using FOS, namely tour guiding activities in order to achieve language learning targets.

\section{Literature Review}

The application of FOS to resolve the problems of MAN 2 Kota Bogor is related to the two FLE teaching approaches that support this study. FOS (Français sur Objectifs Spécifiques) according to Carras et al. [12] is a French-language teaching method for specific purposes. This French teaching method is based on specific fields of expertise, such as tourism, hospitality, and economics. The FOS material provided includes French language proficiency levels ranging from A1- $\mathrm{C} 1$, personalized to the needs of learners. This method considers learners as social actors having to accomplish tasks in a particular field of action. According to F. Goullier [in 13, p. 22-23], a task in this method is a given result of a problem to be solved, of an obligation to be fulfilled, of a goal. The tasks which are real and are at the core of teaching are linked directly to the objectives and therefore to the needs, FOS didactics involve the design of "tailormade" teaching programs on a case-by-case basis, business by profession, based on authentic documents taken from specialized communication. In this study, the French teaching program was given using the FOS method related to the tourism industry, emphasizing the tour guide profession with initial A1-A2 language levels. Tourism as the specific purpose for French teaching is based on the facts that there are historical places in Bogor that often attract tourists. With tourism, we could encourage students to use several forms such as flyers and presentations on history or scenery to express their French language skill. According to the model proposed by Mangiante and Parpette, there are five stages in the FOS method: identifying problems, analyzing needs, collecting teaching materials, transferring materials, and evaluation [14]. These stages are the basis of the study.

However, in Enseigner le FLE (français langue étrangère) Pratique de classe [15], it is stated that FLE has described three didactic approaches in teaching French as a foreign language in a class for a more efficient and accurate teaching program. The three approaches are déterministe et environnementaliste, génétique et cognitiviste, and communicationnelle centrée sur l'apprenant.

\subsection{Déterministe et environnementaliste}

According to Gaonach [in 15, p. 13-14], this approach has six main characteristics: (1) language instructors must motivate their learners to practice the language, because language is seen as a behaviour or a demeanour; (2) the teaching material must be delivered firstly as oral or verbal material; (3) practising a dialogue that includes simulations of situations or actual circumstances is needed because it can encourage language learning; (4) activities that can build the formation of automatism must be practiced; (5) imitation and memorization of a reference or demonstration can help language practice; (6) practise in using the language is essential.

\subsection{Génétique et Cognitiviste}

This approach brings together three different currents: cognitivism, innateism of Chomsky and constructivism of Piaget. The focus of this approach is in the subject's internal processes, especially in the methods of acquiring the knowledge. There are three principals in implementing this approach, namely the idea of an individual subject, ideal, and of a universal. 
The process of acquiring a language can be seen as processing information like a biological program or a mental construction of the subject. For biologists/cognitivists, language is information treated like any other, for Chomsky innateists, language is a specific mental organ, and for constructivists like Piagel, language is a secondary of human intelligence.

\subsection{Communicationnelle centrée sur l'apprenant}

This communicative approach is student-centred. The characteristic of this approach is a functional and pragmatic aspect based language teaching approach used in communication. In other words, teaching is carried out in reliance on utilization, function, and language context in communication. There are four formulas in implementing this approach, namely observation, discussion, practice/exercise, and production.

Déterministe et environnementaliste and Communicationnelle centrée sur l'apprenant were selected based on the needs of students in learning French using the FOS method, which found that the students' French language skills were weak. We considered that these two approaches are suitable for students of MAN 2 Kota Bogor, especially in providing the teaching materials for tour guides.

The activities in the FOS stages according to La rédax d'Agitox [16] are carried out in this study by applying also the two approaches of FLE (student-centered with six main characteristics).

Identifying problems and analyzing needs. Observations and discussions with the teachers as well as the observations in IFI virtual class with students of MAN 2 Kota Bogor. From these observations, researchers obtained information on students' weaknesses: in pronunciation, telling the time, and numbers. As found by Permana and Laksman-Huntley [17], according to Indonesian pronunciation practice, they tend to pronounce the French words as they are written. Forum Group Discussion (FGD) was organized together with MAN 2 Kota Bogor teachers and student representatives by using the Google Meet application. The FGD aimed to discuss the constraints and needs of French teachers and students in MAN 2 Kota Bogor and the level of French language proficiency of the students. From these stages, we found that students do not have enough time to master French as targeted by the teacher. This is due not only to the learning time (45 minutes), but also to there being only 1 teacher for 10 classes in each level in the school, which is a total of 30 classes.

Collecting teaching materials. A workshop for the French teachers of MAN 2 Kota Bogor and publicly open for other high school teachers was held using the distance teaching system using Google Meet. It aims were to provide knowledge of teaching and deciding on the right FOS concentration. Based on the characteristic of the school, which is a madrasa located in the town that has several tourist places, we decided to use French for tourism with several end results such as flyer and oral presentations with the objective to cover all aspects of A1: the ability of introducing, presenting, and describing people, the city, its activities, and tourist places orally or in written form with simple language structure and also phonetically and gramatically correct. The materials are French greetings, vocabulary related to touristic places and activities, present and past tense, and imperative sentences.

Transferring materials. Teaching French language for tourism to students has the purpose of teaching student competences in the French language. This program teaches the skills to become a French speaking tour guide by mastering the following competences: two language competences, namely speaking skill and writing skill. They will be able to correctly 
speak phonetically and gramatically and able to write using a simple stucture that is gramatically correct. As posited by Boukhannouche [18], FOS is the method where there is an essential phase for improving linguistic competences.

Evaluating. To evaluate the result of the experiment, IFI representatives, lecturers from the French Studies Program of FIB UI, and PT Jagaddhita Tourism Consultant act as evaluators on the tour guiding videos for each student group. IFI and lecturers from the French Studies Program of FIB UI evaluated the language aspects while PT. Jagaddhita Tourism Consultant assessed the professional aspect as a tour guide.

\section{Methods}

This study is based on qualitative research whose data sources come from the 15 selected senior year students or those in year XII of MAN 2 Kota Bogor. The criteria of the selected students are those who have completed year XI and made it to year XII with a final score of 8090 in French. This study is conducted in five stages from which data of each stage are gathered to get developmental results. First, after identifying problems through interviewing the school teacher, observing the school syllabus and students' French skill, we prepared a customized teaching syllabus and divided students into 5 groups each consisting of 3 students. Second, we conducted an online French proficiency test consisting of a structure and vocabulary test, writing ability test, and speaking ability test, and later evaluating test results. The structure and vocabulary test as well as the writing ability test is an individual test that is carried out synchronously: students are given 30 minutes to take a multiple-choice structure and vocabulary test via Google Form, then proceed with answering the writing test questions via Google Documents which have been uploaded first on Google Classroom, and worked on for 45 minutes. Meanwhile, the speaking test is a test that is carried out per group asynchronously: each group is asked to create a conversational dialogue based on the communication situation they choose from 2 given themes; each group is given 24 hours to make a recorded video then submit it in Google Classroom. These tests were carried out in order to determine the initial French proficiency level of each student. The results were then used as evaluation material to measure the success of the given solution in this research.

Third, the teaching and learning process. During the teaching and learning process, online quizzes through WhatsApp Group (WAG) are conducted outside of regular lessons. Regular lessons are Tuesday, Thursday, and Saturday from 10 AM to 12 AM (total 24 hours regular study time: 12x sessions @2 hours). During the teaching and learning process, a student's progress was recorded and evaluated based on their quiz scores and participation. We used the evaluation to decide the next activities for better results. Fourth, the execution of the final project as a tour guide in 5 famous tourist attractions in Bogor: Kebun Raya Bogor, Museum Zoologi Bogor, Vihara Dhanagun, Jalan Surya Kencana, and Istana Presiden. Students will demonstrate what they have learned and practiced in online classes by recording a tour-guided video. At this stage, three speakers, namely representatives of Institut Français d'Indonésie (IFI), representatives of French Studies Program of FIB UI, and 
representatives of PT Jagaddhita Tourism Consultant evaluate the results. Evaluators from IFI and French Studies Program assess the video with respect to linguistic aspects, using the following assessment criteria: competence in using tour guiding material in French, pronunciation, intonation and facial expression, sentence structure and vocabulary, gestures, and video creativity (see table 1 for the assessment form in French).

\begin{tabular}{|c|c|c|c|c|c|c|c|c|c|c|}
\hline \multirow[t]{3}{*}{ No } & \multirow[t]{3}{*}{ Group } & \multirow[t]{3}{*}{$\begin{array}{l}\text { Student's } \\
\text { Name }\end{array}$} & $\begin{array}{c}\text { Tour } \\
\text { Guiding } \\
\text { Material } \\
\text { (Opening, } \\
\text { Content, } \\
\text { Closing) }\end{array}$ & Pronunciation & $\begin{array}{l}\text { Intonation } \\
\text { and Facial } \\
\text { Expression }\end{array}$ & $\begin{array}{c}\text { Sentence } \\
\text { Stucture } \\
\text { and } \\
\text { vocabuary }\end{array}$ & Gesture & $\begin{array}{c}\text { Creativity } \\
\text { of the } \\
\text { Video }\end{array}$ & $\begin{array}{l}\text { Final } \\
\text { Score }\end{array}$ & \multirow[t]{3}{*}{$\begin{array}{l}\text { Suggestions } \\
\quad \text { and } \\
\text { Comments }\end{array}$} \\
\hline & & & \multicolumn{7}{|c|}{ Scoring Range } & \\
\hline & & & 30 & 25 & 10 & 25 & 5 & 10 & 100 & \\
\hline
\end{tabular}

Meanwhile, PT. Jagaddhita Tourism Consultant assesses the professional aspect as a tour guide, using the following assessment criteria: tour guiding gestures, presentation on the tourist attraction, attitudes, and video creativity (table 2 is the tour guiding assessment form).

\begin{tabular}{ccccccccc}
\multicolumn{8}{c}{ Table 2. Assessment Form for the Tour Guiding Aspect } \\
\hline \multirow{2}{*}{ No } & Group & $\begin{array}{c}\text { Student's } \\
\text { Name }\end{array}$ & Gesture & $\begin{array}{c}\text { Presentation } \\
\text { on the Turist } \\
\text { Attraction }\end{array}$ & Attitudes & $\begin{array}{c}\text { Creativity of } \\
\text { the Video }\end{array}$ & $\begin{array}{c}\text { Final Score } \\
\text { Suggestions } \\
\text { and } \\
\text { Comments }\end{array}$ \\
\cline { 3 - 7 } & & & & Scoring Range & 10 & 20 & 100 \\
\hline
\end{tabular}

The video assessment is done online and indirectly. The purpose of this activity is to evaluate students transparently. The results of the assessment are used as an evaluation for the entire teaching and learning process.

The fifth stage is the final stage, which is analysis of data sourced from the results of the second to fourth stages and includes initial test results, student development results, and final results. This stage aims to measure the success of the solutions given. The final result is then analysed based on FOS [12 and 16] and FLE theory [15] 


\section{Results and Discussion}

\subsection{Participants of FOS Distance Teaching Lesson}

The initial test demonstrated that the selected students did not have the necessary criteria. The teaching and learning process also showed that the French language proficiency of participants remained inadequate with $85 \%$ of students being weak in two language skills, namely writing and speaking. Weaknesses was also seen in pronunciation, structure, and vocabulary.

The diverse backgrounds of the students-some students are active in selfdevelopment activities during school holiday time, some spend their time at home, and some volunteer to be caretakers at a mosque (a marbot) - are challenging for the teachers who also play a role as researchers in delivering the teaching content. However, by applying Demouy [10] and Bilyalova [11]'s result, we were able to overcome these challenges by providing regular lessons through offering students a flexible assignment deadline, offering an adaptive time and learning space to ask questions via WAG about the teaching materials given, and being allowed to use ICT to accomplish tasks.

During each 2 hours of live teaching sessions, participants were able to follow the lesson very well, even though in the middle of the learning process, for personal reasons, three students from the religion program did not complete the group project. The teaching activities were continued with 12 participants until the end of the syllabus. After taking 1-2 weeks of teaching, the enthusiasm and ability of each participant began to show improvement in comprehending the material and in the French pronunciation system. The enthusiasm, curiosity, and ability of the participants in following the learning process can be seen from their capacity to understand the teaching material in a shorter period of time, resulting in acceleration of the initial teaching plan, so the teachers have to modify the syllabus to adjust to the actual learning situation.

This result shows that contradictory to Hasanah and Saefullah [5], extending learning time could be satisfactory if learning conditions are enjoyable, encouraging and not stressful. However, the study context might influence the satisfying result. Studying during school holiday even though the students have to do other tasks outside due to the COVID-19 pandemic situation involving a flexible schedule for homework and financial support for internet quota data, might be the factors in the research result, which supports Demouy et al. [10] and Bilyalova [11]'s study.

\subsection{FLE (French as a foreign language) distance teaching for high school students}

Following the six main characteristics in déterministe et environnementaliste approach suggested by Gaonach [15] along with the student-centred approach, the activities were as follow. As language instructors we motivated the high school students by giving them an appreciation for their result and answers. Additionally, the materials that they needed or wanted to know about in the form of audio power point or video documents contained explanations with examples and interesting exercises. For example, students read and heard how every French sound is written and pronounced in a power point document placed in the google classroom with an exercise of singing a French song. With this verbal material students learn and can visit the material whenever they need, can practise it by singing and enhance their understanding by being given an explanation of new vocabulary.

Practice is the main activity in this study: students are encouraged, for example, to make sentences to show interesting places in Bogor or to tell the history of the places verbally 
or in writing after they are taught how to be a guide or to use past tenses in a story. Additionally, unconsciously, students are encouraged in automatism, imitation and memorization through quizzes.

The teaching and learning process commenced in June 2020 and ended in July 2020 with three sessions per week in a scheduled period. Each teaching session, except for the quiz, is conducted intensively for 2 hours (120 minutes). The learning agenda consists of 16 sessions in total which divide into 12 lessons and 4 quizzes outside of the regular lessons. Every session is conducted with online helping medias: WhatsApp, Google Meet, and Google Classroom. The demanding learning agenda schedule using various online applications, necessitated researchers subsidizing the internet data costs of the students so that they could fully and conveniently participate in the program.

In each session, the teachers are accompanied by two facilitators, who are final year undergraduate students from the French Studies Program of FIB UI, whose task is to record the participation of students with the help of internet-based media on Google Form. The active participation aspects recorded are the attendance, punctuality in class and assignment submission, participation in asking or answering a question in class, participation outside of the class during a quiz or on an individual learning session, and the quality of the student's quizzes and assignments. After finishing the last session of the compulsory lesson, students were tutored intensively in each group for a week as they created a video tour guide for their final project. These tutoring sessions were first conducted by the teachers focusing on pronunciation and intonation and then proceeded by facilitators under the guidance of the teachers via WAG. With this individual tutoring session, each group was able to convey their ideas and communicate their progress through video production, conveniently.

We, acted as French teachers, delivered the teaching materials gradually, starting with pronunciation, then continued with the structure of tour guide material: the opening, content, and closing sentences, tour guiding, production of tourism flyer, and then proceeded with frequent practice/exercise in both writing competence - to make a guiding script - and speaking competence - to give a virtual-guide presentation-focusing on pronunciation. The teachers implement the formula of observation, discussion, practice/exercise, and production in each teaching material section, corresponding with the two FLE approaches used.

The challenges in distance teaching related to technology use, as stated by Digtyar et al. [1] were also found by the teachers in this program. However, with numerous adequate platforms today, this technology-related problem can be appropriately resolved. It is advisable that, before starting the lesson, the teachers must first examine the problems that could occur related to technology use and prepare appropriate solutions to resolve them. For example, in this research, providing internet data for students is a solution to prevent the possibility of their incapacity in affording the internet data cost.

Another example is the unstable internet connections experienced by the participants. To resolve this condition, the teachers can deliver the teaching materials using other alternatives, for example by writing the material being explained in the chat room of the video conference application, then copy and paste it into another chat room, for example, in the WAG. Therefore, the students who have problems participating in class and those who are unable to join the session can still learn the teaching material provided, and it can even be used as a study reminder for all students and as a way to encourage new discussion forums. These challenges are not found or mentioned in previous studies.

However, our presenting references (observations), imitation and memorization (discussion) activities, as well as regularly practising in using the language, have helped students to more easily understand the teaching materials and later be able to produce the 
expected language output, in both oral and written form. Working in a small group of 3 students is also a helping factor whereby they share what they have learned with others in the group who have missed a teaching session or encourage one another in the objective of finishing the project.

\subsection{Final Result: Virtual Tour Guiding}

By examining the student activity record that has been created since the first session, teachers can decide on the three students with the highest participation points, selecting them as the best students for the teaching program. However, even though there are only three participants selected as the best students, the teachers still paid attention to the individual development of all the remaining 12 students.

Through the collected data, it appears that the students with the highest points are always present on time for every lesson in WAG and Google Meet. The majority of student participation was seen more often by using Google meet rather than WAG (figure 1). This is because the time for Google meet is always reminded beforehand so that the students are prepared while their attention on WAG could be sidetracked by other activities.

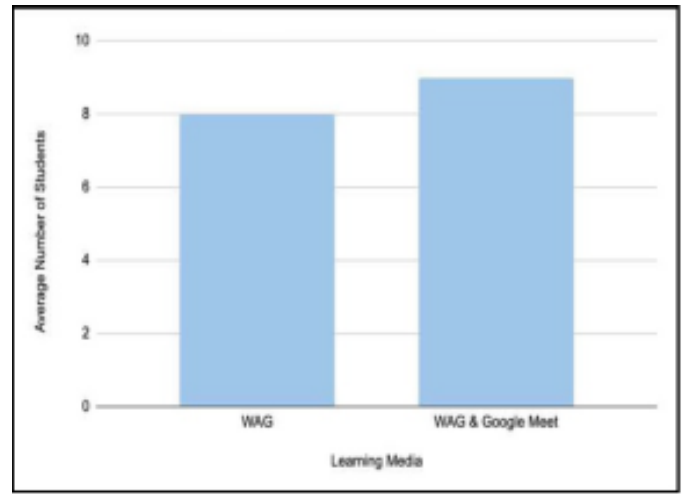

Fig. 1. Attendance Graph

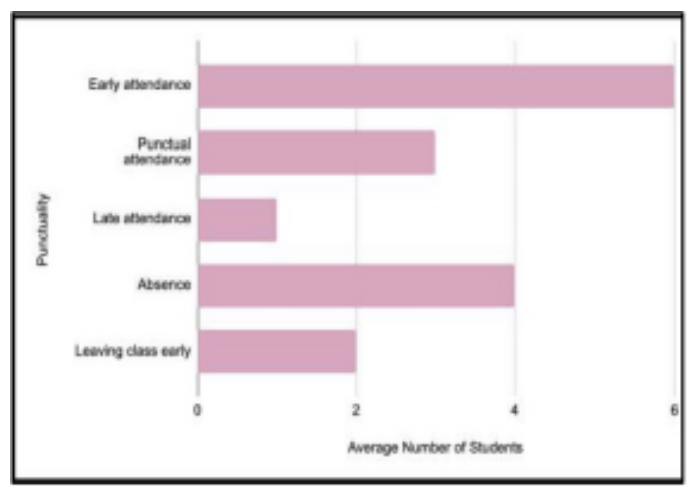

Fig. 2. Punctuality Graph

Nevertheless, figure 2 shows that they sometimes are ready before the lesson even begins. Moreover, they are also active in asking and answering questions during and after the class (figure 3 ) and disciplined in submitting all of the assignments given (figure 4). 


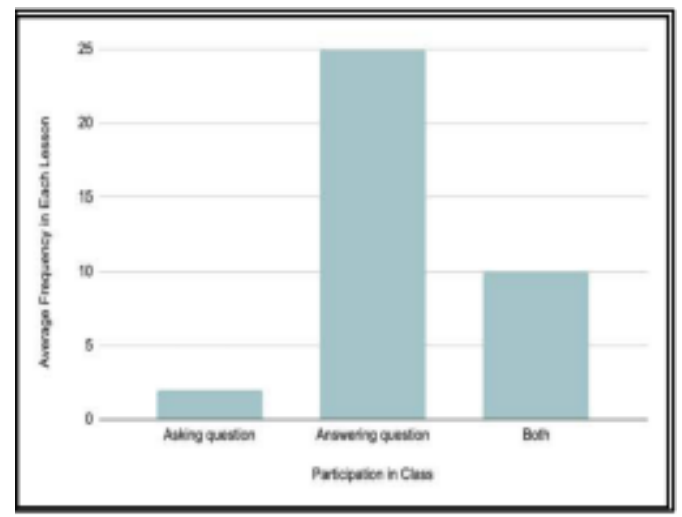

Fig. 3. Participation in Class Graph

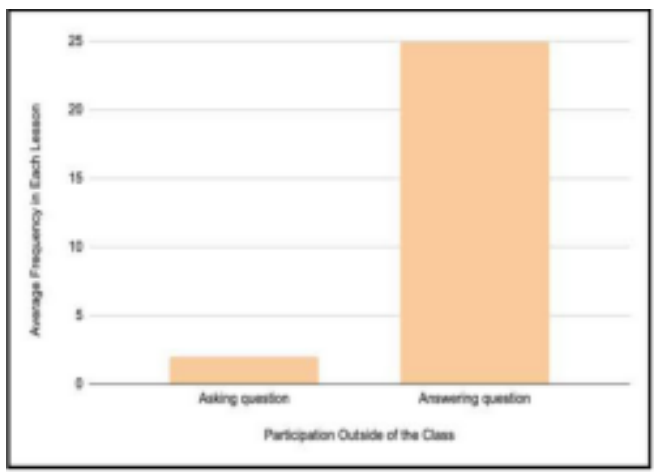

Fig. 4. Participation Outside of Class Graph

Quizzes are a popular activity. Most students tried their best to answer pronunciation and structural questions. Eagerness to reproduce what they have learnt and memorized could be seen in their responses (figure 5).

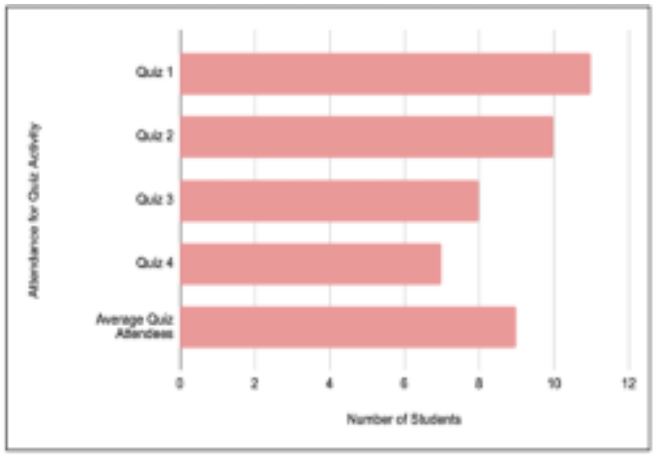

Fig. 5. Attendance Graph for Quiz Activity

Figure 6 shows that with one month of this learning process, the result is acceptable. Meanwhile, students who rarely attend the online classes and submitted assignments do not show the same excellence in improvement. 


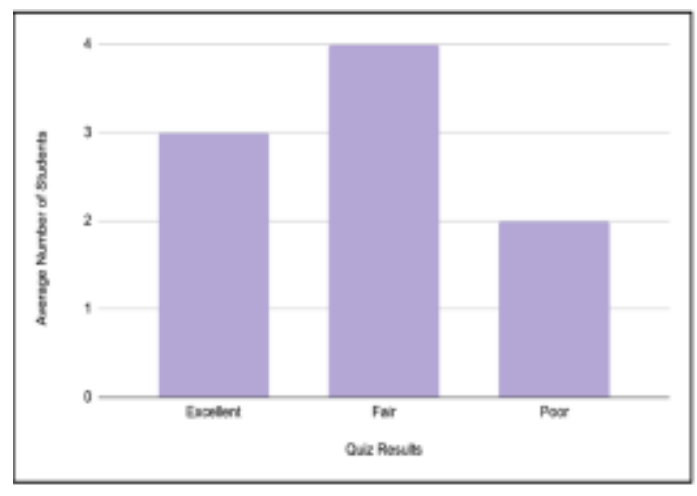

Fig. 6. Quiz results graph.

However, on seeing the program as a whole, practically every student showed massive progress in understanding French, especially in pronunciation and sentence structure. Thus, the A1 target is achieved before they started year 12. Their enthusiasm in finishing their group project with a good video overcame the difficulties of reserving time to practice with tutors, correcting the text, and merging the recording and visual documents. This progress can be seen from their tour guiding videos where they can pronounce every French word correctly and adequately throughout the video while using accurate intonation, such as rising intonation, to ask questions and to interact with visitors; these skills had not been mastered before the learning program. Furthermore, the video presentation shows that students also managed to present the right tour guiding gestures such as hand movements and facial expressions.

Positive results are also indicated from the final project scores and comments given by the evaluators for each video. The evaluators appreciated the final results of the students; one of them even suggested to post the videos on every social media page managed by IFI and send them to Wonderful Indonesia (Table 3). And the projects were found to be acceptable from the tour guiding point of view (table 4) too. 
Table 3. Recapitulation of students' final scores and comments as a tour guide

\begin{tabular}{|c|c|c|c|c|c|c|c|}
\hline \multirow[t]{3}{*}{ No } & \multirow[t]{3}{*}{ Group } & Gestures & $\begin{array}{c}\text { Presentation } \\
\text { on the Turist } \\
\text { Attraction }\end{array}$ & Attitudes & $\begin{array}{c}\text { Creativity } \\
\text { of the } \\
\text { Video }\end{array}$ & Final Score & \multirow[t]{3}{*}{ Suggestions and Comments } \\
\hline & & \multicolumn{5}{|c|}{$\begin{array}{l}\text { Scoring Range } \\
\end{array}$} & \\
\hline & & 20 & 50 & 10 & 20 & 100 & \\
\hline 1 & Jalan Surya Kencana & 14 & 40 & 8 & 14 & 76 & $\begin{array}{l}\text { Tourist attractions' potential can be } \\
\text { discovered further }\end{array}$ \\
\hline 2 & $\begin{array}{l}\text { Museum Zoologi } \\
\text { Bogor }\end{array}$ & 14 & 44 & 8 & 18 & 84 & The video is original and fresh \\
\hline 3 & Vihara Dhanagun & 18 & 40 & 8 & 14 & 80 & $\begin{array}{l}\text { The interaction between tour guides and } \\
\text { visitors has been built }\end{array}$ \\
\hline 4 & Kebun Raya Bogor & 14 & 44 & 8 & 16 & 82 & $\begin{array}{l}\text { More guiding materials could be } \\
\text { delivered }\end{array}$ \\
\hline
\end{tabular}

Table 4. Recapitulation of students' final scores and comments from aspect of French language

\begin{tabular}{|c|c|c|c|c|c|c|c|c|c|}
\hline \multirow[t]{3}{*}{ No } & \multirow[t]{3}{*}{ Group } & $\begin{array}{c}\text { Tour Guiding } \\
\text { Material } \\
\text { (Opening, } \\
\text { Content, Closing) }\end{array}$ & Pronunciation & $\begin{array}{l}\text { Intonation } \\
\text { and Facial } \\
\text { Expression }\end{array}$ & $\begin{array}{l}\text { Sentence } \\
\text { Stucture } \\
\quad \text { and } \\
\text { vocabuary }\end{array}$ & Gesture & $\begin{array}{l}\text { Creativity } \\
\text { of the } \\
\text { Video }\end{array}$ & $\begin{array}{l}\text { Final } \\
\text { Score }\end{array}$ & \multirow[t]{3}{*}{$\begin{array}{l}\text { Suggestions and } \\
\text { Comments }\end{array}$} \\
\hline & & \multicolumn{7}{|c|}{ Scoring Range } & \\
\hline & & 30 & 25 & 10 & 25 & 5 & 10 & 100 & \\
\hline 1 & $\begin{array}{l}\text { Jalan Surya } \\
\text { Kencana }\end{array}$ & 22,5 & 19,5 & 7,5 & 16 & 2,5 & 8 & 76 & $\begin{array}{l}\text { Impressive video } \\
\text { with excellent } \\
\text { pronunciation }\end{array}$ \\
\hline 2 & $\begin{array}{l}\text { Museum } \\
\text { Zoologi } \\
\text { Bogor }\end{array}$ & 20 & 13,5 & 6 & 17,5 & 2 & 9,3 & 68,3 & $\begin{array}{l}\text { The video qualty is } \\
\text { outstanding }\end{array}$ \\
\hline
\end{tabular}




\begin{tabular}{|c|c|c|c|c|c|c|c|c|c|}
\hline 3 & $\begin{array}{l}\text { Vihara } \\
\text { Dhanagun }\end{array}$ & 22,5 & 17,5 & 7 & 17,5 & 4,5 & 8,3 & 77,3 & $\begin{array}{l}\text { Excellent } \\
\text { presentattion with } \\
\text { celar pronunciation }\end{array}$ \\
\hline 4 & $\begin{array}{l}\text { Kebun Raya } \\
\text { Bogor }\end{array}$ & 25 & 20 & 6,5 & 18,5 & 3 & 7,3 & 80,3 & $\begin{array}{l}\text { The supporting } \\
\text { images chosen are } \\
\text { unique; the } \\
\text { presentation is } \\
\text { entertaining }\end{array}$ \\
\hline
\end{tabular}

Based on feedback from the students given after the activities, $85 \%$ of the participants found that they improved their pronunciation and $92 \%$ of them stated that the program gave them the opportunity to gain better and more knowledge in French. $42 \%$ of the participants expressed their interest to practice tour-guiding on site or create a blog or even organize a festival to promote their region.

\section{Conclusion}

The complementing activities of student centred and customized French teaching trial with a specific purpose (FOS) as a tour guide for the students of MAN 2 Kota Bogor, show that FOS can be successfully used because FOS has a tangible result that can drive student motivation in learning French. In this case, to obtain level A1 competency. This outcome does not support findings in [5] but is consistent with the results discovered by Bilyalova [11] who stated that technology use in teaching with specific objectives could motivate learners. The MAN 2 Kota Bogor students are motivated when using an on-line learning process and technology that is familiar to them, which has also been used in their regular lesson at school. This motivation arises because FOS teaching has clear learning objectives; hence the final results are more apparent than a regular French teaching lesson with no specific objectives. With the FOS method implemented within student groups, the teachers provide a learning space for students to improve by giving various exercises and practice that needs to be accomplished by the participants as well as the freedom to express themselves through the production of language outputs, in written or oral form. For example, when they are writing a description and explanation of a particular tourist attraction. The students are also allowed to work together in groups, which teaches teamwork and empathy for other group members who might need help. Therefore, progress is not only accomplished in terms of language but also in an individual's (student) characteristics: stimulating their imagination, social interaction, and strengthening students' mentality. This progress is in line with previous research results [6] and [7], which stated that teaching foreign languages with a specific purpose can promote a learner's language competence as well as their selfcompetence. However, one must pay attention to these details when applying the FOS method: the interest of students and the way teachers encourage students to review teaching materials. One of the methods used in this research is by giving quizzes outside of the regular 
teaching schedule, which are conducted routinely once a week through the WAG. Quizzes create a healthy competition environment between students, thus encouraging students to be enthusiastic in their study. 
Agreeing with Digtyar et al. [1], this study also proves that in distance teaching, technology-related problems cannot be avoided. Therefore, responsive actions are demanded of the teachers in providing the teaching plan (syllabus): sorting out the material that can be given synchronously or asynchronously. Furthermore, teachers must also prepare solutions to possible challenges that could emerge during the teaching process. Researchers also found that the teaching approach in FLE, which is intended for a face-to-face class [15], can be implemented for distance teaching (online).

For Indonesian high schools, especially state high schools that tend to reduce teaching class time to a minimum using a minimum number of teachers for less popular languages, this procedure can be used to achieve minimum targets, in this case, A1 French competency. With A1 in French, one can communicate easily with French native speakers who are known to be patient and cooperative with foreigners. Collaborative learning in groups can support teachers to address the subjects outside of the classroom. However, this study should be extended into more schools with different purposes than tourism, for example hospitality trades, which might give more and better perspective to students with respect to professionalism.

Acknowledgments. This work is supported by Program Pengabdian dan Pemberdayaan Masyarakat UI 2020 funded by Direktorat Pengabdian dan Pemberdayaan Masyarakat Universitas Indonesia.

\section{References}

[1] Digtyar, O., Fomina, N., Anyushenkova, O., Esina, L., and Zakirova, E. The problems of distance learning education while teaching foreign languages at the non-linguistic higher school. Proceedings of EDULEARN19 Conference. 2019. pp. 10531-10535.

[2] Google Maps Team. "Location Map of MAN 2 Kota Bogor from Universitas Indonesia Depok". Google $\quad$ Maps. 2020 https://www.google.co.id/maps/dir/FIB+UI,+Pondok+Cina,+Depok+City,+West+Java/MAN+2+K ota+Bogor.,+Jl.+Raya+Bogor++Sukabumi+No.56,+RT.01\%2FRW.03,+Baranangsiang,+Kec.+Bog or+Tim.,+Kota+Bogor,+Jawa+Barat+16143/@6.483831,106.740807,12z/data=!3m1!4b1!4m14!4 $\mathrm{m} 13$ !1m5!1m1!1s0x2e69ec18478d61d3:0x73e4ae0bd22bb53f!2m2!1d106.8280538!2d6.3631636! $1 \mathrm{~m} 5$ !1m1!1s0x2e69c5dd13a9205f:0xfde0eee571ac73a2!2m2!1d106.8080281!2d6.6062372!3e3 (accessed June 14, 2020).

[3] France Langue. "Niveaux de français du CECRL". FranceLangue.fr. 2020. https://www.francelangue.fr/niveaux-de-francais/ (accessed March 9, 2020).

[4] Breton, G., Lepage, S., and Rousse, M. Réussir Le DELF A1. Didier, Paris, France. 2010.

[5] Hasanah, F., and Saefullah, N. H. Strategi belajar efektif bagi pemelajar pemula Bahasa Prancis di Madrasah Aliyah Negeri Model Babakan Ciwaringin Majalengka-Cirebon. Dharmakarya: Jurnal Aplikasi Ipteks untuk Masyarakat. 2017. Vol. 6, pp. 200-203.

[6] Pisarenko, V., and Bondarev, M. Infographics use in teaching foreign languages for specific purposes. Recent Patents on Computer Science. 2016. Vol. 9, pp. 124-132.

[7] García-Sánchez, S. Ubiquitous interaction for ESP distance and blended learners. Journal of Applied Research in Higher Education. 2016. Vol. 8 pp. 489- 503.

[8] Didmanidze, I., and Bagrationi, I. The issue of student distance communication and collaboration (For foreign language teaching). Cross-cultural Studies: Education and Science. 2018.Vol. 3, pp. 2129.

[9] Niyibizi, E., Sibomana, E., and Perumal, J. Learning to teach writing through a distance education programme: Experiences of Rwandan secondary school English teachers. Reading \& Writing Journal of the Reading Association of South Africa. 2019. Vol. 10 pp. 1-10. 
[10] Demouy, V., Jones, A., Kan, Q., Kukulska-Hulme, A., and Eardley, A. Why and how do distance learners use mobile devices for language learning? The EUROCALL Review. 2016. Vol. 24 pp. 1024.

[11] Bilyalova, A. ICT in teaching a foreign language in high school. Procedia - Social and Behavioral Sciences. 2017. Vol. 237 pp. 175-181.

[12] Carras, C., Tolas, J., Kohler, P., and Szilagyi, E. Le Français sur Objectif Spécifique et la classe de langue. Université Grenoble Alpes. 2007.

[13] Goullier, F. Les outils du conseil de l'Europe en classe de langue - Livre: CECR et Portfolio européen des langues. Didier, Paris, France. 2006.

[14] Mangiante, J-M., and Parpette, C. Le Français sur Objectif Spécifique: de l'analyse des besoins à l'élaboration d'un cours. Hachette, Paris, France. 2004.

[15] Professeurs à l'ILCF-ICP. Enseigner le FLE (français langue étrangère) Pratique de classe. Belin, Paris, France. 2005.

[16] La rédax d'Agitox. 2020. "Le FOS, Français sur Objectifs Spécifiques". Agi.to.https://agi.to/enseigner/carnets-pedagogiques/fos-francais-sur-objectifsspecifiques/ (accessed March 9, 2020).

[17] Permana, B. A., and Laksman-Huntley, M. Phonemic Interference and Overregularization in the /s/ and $/ / /$ Phonemes Realization in French. Jurnal Pendidikan Bahasa dan Sastra. 2020. Vol. 20 pp. 71-83.

[18] Boukhannouche, L. Le français sur objectif spécifique (FOS): méthodologie pour une réalisation didactique efficace. Université de Blida 2. 2017. 